\title{
Diabetes Mellitus, Dietary Pattern And Diseases Burden in Indonesia: A Mini Review
}

\author{
Ice Yolanda Puri ${ }^{1,2}$ \\ \{ice.yolandapuri@gmail.com\} \\ ${ }^{1}$ Faculty of Public Health, Andalas University, Padang, West Sumatera, Indonesia \\ ${ }^{2}$ Doctoral Student of Faculty of Medicine and Health Sciences, Universiti Putra Malaysia, 43400 UPM \\ Serdang, Selangor, Malaysia
}

\begin{abstract}
T2DM in Indonesia has increased dramatically in Padang, West Sumatra, the prevalence was $1.3 \%$ in 2013 and increased slowly in 2018 (1.8\%). The aims of review are to determine the risk factors of Diabetes Mellitus (DM) in Indonesia and to determine Indonesian DM prevention program. Behavior aspects of food intake pattern food choices like fruit and vegetable, unhealthy diet, convenience food. $94 \%$ of Indonesian did not consume an adequate amount of fruit and vegetable. $77.3 \%$ of people above $\geq 10$-year-old add seasoning to their food which is high in salt, $53.1 \%$ consume sweet and $40.7 \%$ consume fatty food. Indonesia has a food pattern, which was prepared in mid-morning, then the same menus were followed for lunch and dinner. Indonesian daily basic dishes are steamed rice, a hot fried dish and or coconut milk dish. The focus of Posbindu is to provide general healthy eating education for the prevention and management of Non-Communicable Chronic Diseases (NCD) including T2DM, cardiovascular disease, cancer, and obesity.
\end{abstract}

Keywords: Diabetes Mellitus, Risk Factors, Indonesian Public Health Care program

\section{Introduction}

The prevalence of diabetes worldwide is estimated at around 8.5\% [1], South-East Asia has prevalence $10.1 \%$ in the third position, and Indonesia was in the sixth rank with 10.3 million or $7.0 \%$ people with diabetes mellitus. Among these, T2DM is the most common with $90-95 \%$ of diagnosed cases [2]. Diabetes Mellitus is one of the Non-Communicable Diseases (NCD). T2DM in Indonesia has increased dramatically from $7.0 \%$ in 2017 to $10.9 \%$ in 2018 . In Padang, West Sumatra, diabetes prevalence was $1.3 \%$ in 2013 and increased slowly in 2018 (1.8\%) [3]. The majority of T2DM were not able to achieve optimal glycaemic glucose control measured using $\mathrm{HbAlc}$ with a target of less than $<6.5 \%$ [6] (WHO, 2014). In Indonesia (North Sumatera and Manado) the average $\mathrm{HbAlc}$ level was around 8.6-8.7\% indicating poor glycemic control among people with T2DM in Primary Health Clinic [7](Rusdiana et al., 2018) [8].

Meanwhile, a 37\% cause of death in Indonesia in 2012 was cardiovascular diseases and stroke $21.1 \%$ in 2014. It was followed by other Asian countries India, Thailand, Myanmar, Nepal, Sri 
Lanka, Bangladesh which have the same cause of death in 2014 [6]. The highest risk factors of NCD in Indonesia in 2007 and 2013 were $93.6 \%$ and $93.5 \%$ respectively due to low vegetable and fruit intake. However, NDCs prevalence in Indonesia in 2013 was $25.8 \%$ as result as hypertension [9]. WHO in 2016 reported that DM prevalence in Indonesia in 2016 was because of overweight (24.4\%) [10]. DALYs reported that NCDs the highest rank risk factors were high systolic blood pressure in Malaysia.

Indonesian Ministry of Health (MoH) and GERMAS (Gerakan Masyarakat Hidup Sehat/Community Empowerment) have NCDs prevention and control policy. The program has indicators following global target, national mid-term development plan, $\mathrm{MoH}$ strategy plan for NCDs, National Action Plan for NCDs, Community Empowerment (GERMAS), the minimum standard for health services, healthy Indonesian program with a family approach.

National Nutrition Strategy paper of Indonesia has a policy for strengthening institutions at central and regional levels for making a decision, focus on counseling, introducing communication for behavior, improving health facilities. For improving the information system, the Indonesian government developed models for identifying effective strategies [11]. 


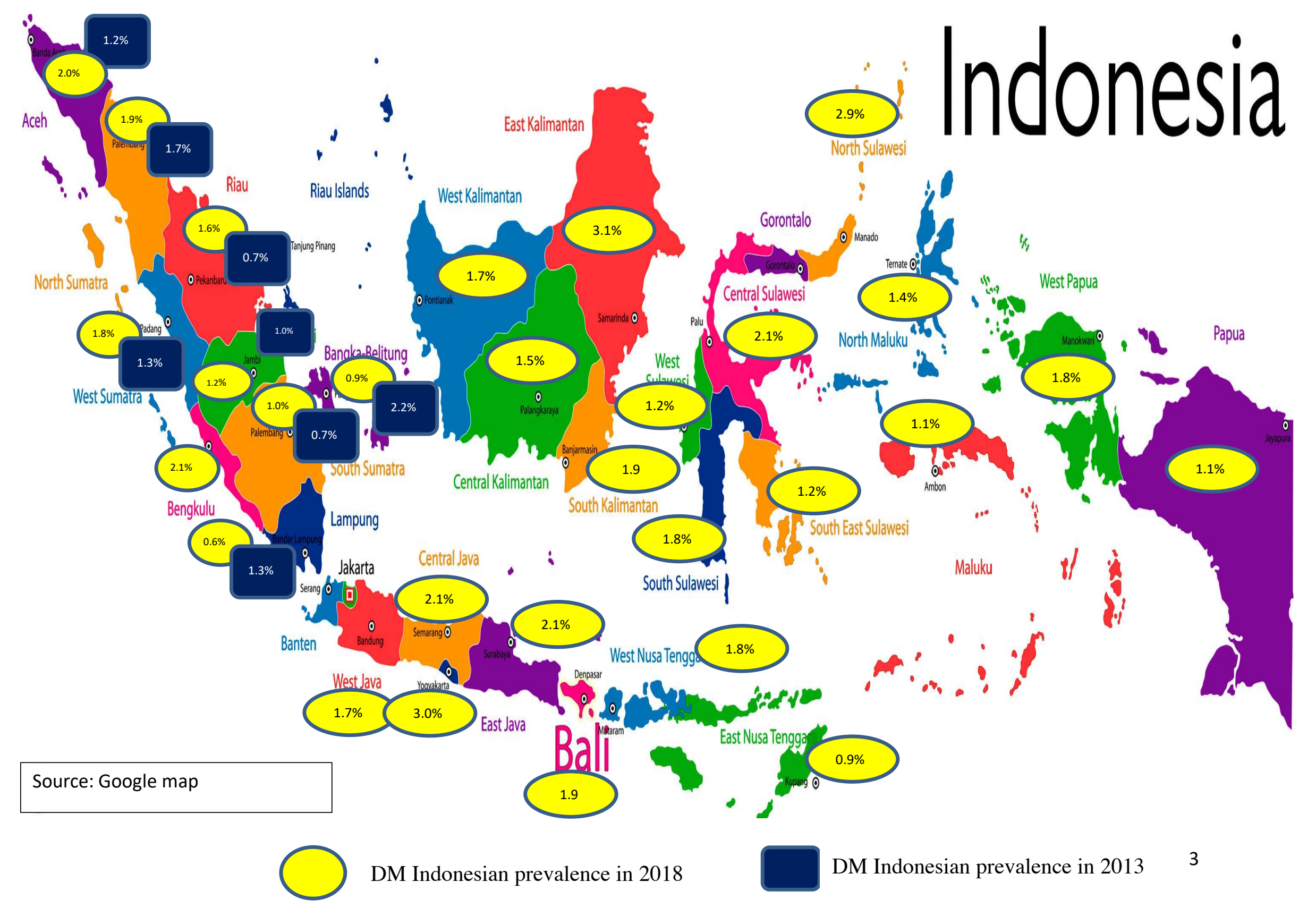




\section{Methods}

The journals were published from 1999 to 2018 and searched using Mesh, Pubmed, and Consort. We searched by using keywords "Diabetes Mellitus, Non Communicable Diseases", "Diabetes Mellitus and risk factors", "Diabetes Mellitus and Indonesian Non Communicable Diseasess Program".

\section{Results}

[12] Lin., K.G., et al 2016 described that Most NCDs were strongly associated and causally linked with four behaviors in Southeast Asia following were tobacco use, physical activity, unhealthy diet, and the harmful use of alcohol. NCDs risk factors in 2013 were low vegetable and fruit intake. An unhealthy diet and unbalance diet had prevalence $93.5 \%$ were higher as risk factors of NCDs and it was followed by smoking (56.7\%), tobacco consumption (36.3\%), and obesity (26.2\%) respectively [3] [13] (Riskesdas., 2007 and 2013). Meanwhile, Indonesia has obesity prevalence in 2018 was $21.8 \%$. Central obesity in 2007, 2013, and 2018 were $18.8 \%, 26.6 \%$ and $31.0 \%$ respectively.

Disability-Adjusted Life Years (DALYs) 2016 found that Ischaemic heart disease and hemorrhagic stroke are Indonesia's first and second leading causes of premature mortality. The

dominant position of these causes reflects high levels of systolic blood pressure and smoking. Age-standardized DALY rates attributable to elevated systolic blood pressure in Indonesia were among the highest in the world in 2016, and the highest found outside of eastern and central Europe. DALY rates attributable to tobacco smoking were similarly high. The smoking prevalence for the population is $28.5 \%$. Men were $59 \%$ while women were only $1.6 \%$. The rural area was slightly higher (29.1\%) compared to urban $(27,9 \%)$. 
Table 1. International Experience in Selection of NCD Prevention and Management Intervention (Best Buys Intervention)

\begin{tabular}{|c|c|}
\hline Risk/Disease & Intervention \\
\hline $\begin{array}{l}\text { Use of Tobacco } \\
\text { Products }\end{array}$ & $\begin{array}{l}\text { 1. Tax increases } \\
\text { 2. Free-Smoking Zone at the workplace and public places } \\
\text { 3. Health information and warnings } \\
\text { 4. Banning of cigarette commercials, promotion and sponsorships }\end{array}$ \\
\hline $\begin{array}{l}\text { Consumption of } \\
\text { dangerous alcohol }\end{array}$ & $\begin{array}{l}\text { 5. Tax increases } \\
\text { 6. Restriction of access to retail alcohol } \\
\text { 7. Ban on advertisement of alcoholic drinks }\end{array}$ \\
\hline $\begin{array}{l}\text { Unhealthy diet and } \\
\text { lack of physical } \\
\text { activity }\end{array}$ & $\begin{array}{l}\text { 8. Reduction of salt intake from meals } \\
\text { 9. Replacing trans fat with polyunsaturated fat in diets } \\
\text { 10. Campaign through mass media on balanced diet and physical activities }\end{array}$ \\
\hline $\begin{array}{l}\text { Cardiovascular } \\
\text { disease and } \\
\text { diabetes }\end{array}$ & $\begin{array}{l}\text { 11. Counseling and multi-drug therapy for population running a high risk of suffering } \\
\text { heart attack and stroke, including for patients who are suffering from cardiovascular } \\
\text { disease. } \\
\text { 12. Treatment of heart attack with aspirin }\end{array}$ \\
\hline Cancer & $\begin{array}{l}\text { 13. Hepatitis B immunization to prevent liver cancer } \\
\text { 14. Screening for and treatment of pre-cancer lesions to prevent cervical cancer }\end{array}$ \\
\hline
\end{tabular}

Source: World Health Organization and World Economic Forum. From Burden to "Best Buys": Reducing the Economic Impact of NONCOMMUNICABLE DISEASESs in Low- and Middle-Income Countries. Geneva, 2011

Indonesia was the world's highest daily smoking rate for males: in 2016, more than half of males older than 10 years smoked daily. Two-thirds of Indonesian women are regularly exposed to second-hand smoke [14]. Yet to sign the WHO Framework Convention on Tobacco Control- the only country in Asia.

Behavior aspects of food intake pattern food choices like fruit and vegetable, unhealthy diet, convenience food. Because Riskesdas data 2013 found that $94 \%$ of Indonesian did not consume an adequate amount of fruit and vegetable. An article in the International Journal of Nutrition and Food Sciences in 2014 told that there were four stages in Nutrition transition which had a relationship with NCDs. The stages were stated from stages 1-paleolithic man hunter-gather, stages 2-settlement begins, famine emerges, stages 3-Industrialization, famine declines, and stages 4-NCDs. All of the stages described that how was the changes in food gathering, the identification of food variation, replacement of food processing which involves infectious diseases, stunting, and mortality. Finally, the last stages had NCDs which were influenced by urbanization, economic growth, mass media growth, technological changes for work, food processing and leisure activities.

Riskesdas 2013 found that $77.3 \%$ of people above $\geq 10$-year-old add seasoning to their food which is high in salt, $53.1 \%$ consume sweet and $40.7 \%$ consume fatty food. Indonesia has a food pattern, which was prepared in mid-morning, then the same menus were followed for lunch and 
dinner. The menus should be provided in hot food eaten, sweet food or hot, food and spicy events [15].

Indonesian daily basic dishes are steamed rice, a hot fried dish and or coconut milk dish. Comparing to lunch which is the most important meal of the day, breakfast has minimal variation. Carbohydrate comes from cassava, corn, sago or noodles and fish as a protein source, which was consumed for four to six times every week. Meanwhile, meat and chicken was usually provided for special events [15].

Table 2. Prevalence (\%) of NCD Risk Factors for 2007 and 2013 in Indonesia

\begin{tabular}{|c|c|c|c|}
\hline No. & NCD Risk Factors & 2007 & 2013 \\
\hline 1 & Prevalence of Tobacco consumption (aged $\geq 15$ years) & 34.7 & 36.3 \\
\hline 2 & Prevalence of smoking (aged $10-18$ years) & $\mathrm{N} / \mathrm{A}$ & 7.2 \\
\hline \multirow[t]{3}{*}{3} & Prevalence of smoking (aged $\geq 10$ years) & $\mathrm{N} / \mathrm{A}$ & \\
\hline & - Female & $\mathrm{N} / \mathrm{A}$ & 1.9 \\
\hline & - Male & $\mathrm{N} / \mathrm{A}$ & 56.7 \\
\hline 4 & Prevalence of low physical activity (aged $\geq 10$ years) & 48.2 & 26.1 \\
\hline 5 & Prevalence of low vegetable $\&$ fruit intake (aged $\geq 10$ years) & 93.6 & 93.5 \\
\hline 6 & Prevalence of alcohol consumption & 4.6 & N/A \\
\hline 7 & $\begin{array}{l}\text { Prevalence of dangerous alcoholic drink consumption ( } \geq 5 \\
\text { standard per day) }\end{array}$ & 0.6 & $\mathrm{~N} / \mathrm{A}$ \\
\hline \multirow[t]{3}{*}{8} & Obesity (BMI $>25$, age $\geq 18$ years) & 14.4 & 26.2 \\
\hline & - Female & 14.8 & 32.9 \\
\hline & - Male & 13.9 & 19.7 \\
\hline 9 & Central obesity (Male $\&$ Female aged $\geq 18$ years) & 18.8 & 26.6 \\
\hline
\end{tabular}

Source: Riskesdas2007 dan 2013

Particularly in NCDs following GERMAS, MoH has the Pos Binaan terpadu (Posbindu) program to prevent and control NCDs. Pos Binaan Terpadu (Posbindu) is an integrated education program under Puskesmas (Public Health Service Center (PHSC)). It was established in 2010. Indonesia has 33.679 Posbindu. The focus of Posbindu is to provide general healthy eating education for the prevention and management of Non-Communicable Chronic Diseases (NCD) including T2DM, cardiovascular disease, cancer, and obesity [16] [17] . 


\section{JUMLAH POSBINDU PTM PER DESEMBER 2017 33.679 (24.9\%) POSBINDU}

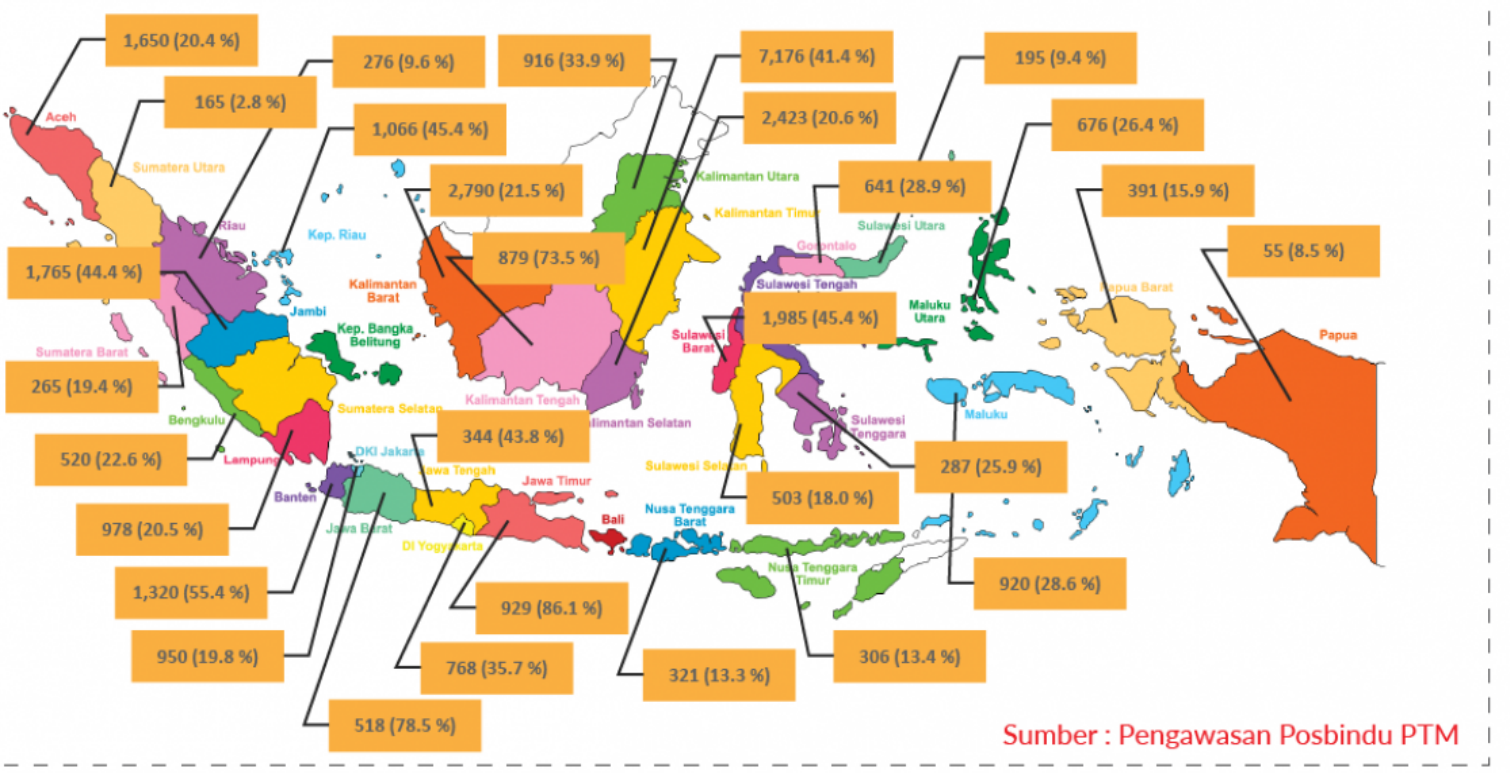

Figure.1 The Number of POSBINDU in Indonesia on 2017

The guideline provided an explanation, information and guideline several defines, government regulation, and monitoring and evaluation questionnaires. Based on NCD management guidelines, there was a number questionnaire to monitor and evaluate NCD activities including T2DM. The questionnaire was management, monitoring, services, measurement tools, Posbindu services, Education and counseling tools, drug management, and the amount T2DM patients who visit Posbindu [18].

Guideline practical for cadres explained measurements of Blood Pressure, Blood Glucose, Body Mass Index (BMI), nutrition education and counseling, healthy lifestyle education behavior, and curriculum. There was guideline specific of individual and family history of T2DM questionnaire, Posbindu activities monitoring questionnaire.

It is crucial to set goals with patients educators and or health professionals and started using nutrition assessments. The contents of nutrition assessments are medical records, family history, life stage, cultural background, current diabetes knowledge, and self-management skills and behavior, health literacy level, and physical abilities and limitation, and income [19]. 
Table. 3 Outputs From NCD Prevention and Management Activities as up to 2015

\begin{tabular}{|c|l|c|c|c|c|}
\hline \multirow{2}{*}{ NO } & \multicolumn{2}{|c|}{$\begin{array}{c}4 \\
\text { INDICATORS }\end{array}$} & \multicolumn{4}{|c|}{ OUTPUTS } \\
\cline { 3 - 6 } & up to December 2014 & up to November 2015 \\
\cline { 3 - 6 } & $\mathrm{N}$ & $\%$ & $\mathrm{~N}$ & $\%$ \\
\hline 1 & $\begin{array}{l}\text { PUSKESMAS organizing integrated NCD } \\
\text { management }\end{array}$ & 2,057 & 21.3 & 2,936 & 30.4 \\
\hline 2 & $\begin{array}{l}\text { Villages/kelurahan organizing NCD Education } \\
\text { Posts }\end{array}$ & 3,723 & 4.7 & 6,860 & 8.6 \\
\hline 3 & $\begin{array}{l}\text { Women within the 30-50 age bracket who are } \\
\text { early-detected to have cervical and breast cancer }\end{array}$ & 904,099 & 2.45 & $1,025,432$ & 2.8 \\
\hline 4 & $\begin{array}{l}\text { Districts/cities implementing non-smoking zones } \\
\text { in at least 50\% of the local schools }\end{array}$ & 26 & 5,0 & 43 & 8,3 \\
\hline 5 & $\begin{array}{l}\text { Districts/cities organizing medical check-ups for } \\
\text { drivers in major terminals. }\end{array}$ & 14 & 2.7 & 62 & 11.7 \\
\hline
\end{tabular}

Nutrition management for outpatients is cover by the Public Health Service Center which has Posbindu to manage individuals with DM. Posbindu has the responsibility and focuses on the selfmanagement of T2DM every month in PHSC. Nutrition education in Posbindu is provided for all Indonesian with every month. Cadres educate the patients around the Posbindu area which is completed with Pospindu KIT measurements. They are Blood pressure, glucometer, anthropometry, waist circumference, and a logbook[18].

In management DM patients Protocol at PHSC, T2DM patients will have nutrition counseling based on a suggestion from a medical doctor. Then, the nutritionist will record the number of patients who are given nutrition counseling every month. Posbindu has Buku Pintar Kader Posbindu (Posbindu Cadre Guideline) for Non-Communicable Diseases (NCD). However, several barriers of DM health system in Indonesia such as Few Diabetes educators; patient education levels, clinics, and a medical doctor were scarce in a rural area. Besides that, there was a significant correlation between diseases, and treatment education, and HbA1c outcomes [20]. 
Table. 4 The indicators of Posbindu program

\begin{tabular}{|c|l|c|c|c|c|}
\hline \multirow{2}{*}{ NO } & \multicolumn{1}{|c|}{ INDICATORS } & \multicolumn{4}{|c|}{ OUTPUTS } \\
\cline { 3 - 6 } & \multicolumn{2}{|c|}{ up to December 2014 } & up to November 2015 \\
\cline { 3 - 6 } & & $\mathrm{N}$ & $\%$ & $\mathrm{~N}$ & $\%$ \\
\hline 1 & $\begin{array}{l}\text { PUSKESMAS organizing integrated NCD } \\
\text { management }\end{array}$ & 2,057 & 21.3 & 2,936 & 30.4 \\
\hline 2 & $\begin{array}{l}\text { Villages/kelurahan organizing NCD Education } \\
\text { Posts }\end{array}$ & 3,723 & 4.7 & 6,860 & 8.6 \\
\hline 3 & $\begin{array}{l}\text { Women within the 30-50 age bracket who are } \\
\text { early-detected to have cervical and breast cancer }\end{array}$ & 904,099 & 2.45 & $1,025,432$ & 2.8 \\
\hline 4 & $\begin{array}{l}\text { Districts/cities implementing non-smoking zones } \\
\text { in at least 50\% of the local schools }\end{array}$ & 26 & 5,0 & 43 & 8,3 \\
\hline $\mathbf{5}$ & $\begin{array}{l}\text { Districts/cities organizing medical check-ups for } \\
\text { drivers in major terminals. }\end{array}$ & 14 & 2.7 & 62 & 11.7 \\
\hline
\end{tabular}

Following GERMAS, the community develops private organizations to provide nutrition education class who involve the head of rural, DM patients, cadre (volunteer), and health professionals under the Posbindu program. The nutrition education program is run every month which has a nutrition education class using certain tool kits, exercise, nutritional status measurement, and glycemic control measurement. For this program, all of the measurements will be reported in the annual report. The topics of nutrition education are the Indonesian food pyramid, balance diet, DM diet management, DM measurement, DM menus, and exercise.

Indonesia $\mathrm{MoH}$ made a healthy Indonesian program which includes blood pressure and glycemic measurement for all citizens above 15 years old. The program suggested all family member stop smoking and not to smoke. The program has to be implemented all over Indonesia in 2019. The purpose of the program is Advocacy and partnership inter-program and inter-sector, Strengthening of health service capacity for risk factor early detection, diagnosis, and integrated prompt treatment of NCD cases, Community empowerment with health promotion, prevention and reducing NCSs risk factorial, Strengthening surveillance, monitoring, and NCDs researches.

\section{Developing Health Promotion Media}

1. Developing health professional teamwork and developing advocacy among Ministries

2. Developing module, guideline, tool kits for health promotion media, and Validity and reliability module, guideline and tool kits before launching.

3. Establishing and empower the local organization to be involved in health professional teamwork. For example head rural and cadre (volunteer health worker). Then, Join the program in community social activities, such as social gathering and social networking. 
Guideline practical for cadres explained measurements of Blood Pressure, Blood Glucose, Body Mass Index (BMI), nutrition education and counseling, healthy lifestyle education behavior, and curriculum. National Nutrition Strategy paper of Indonesia has a policy for strengthening institutions at central and regional levels for making a decision, focus on counseling, introducing communication for behavior, improving health facilities [21].

\section{Intervention and Implementation a Health Promotion Program}

1. Launching the module, guideline, tool kits, policy and regulation

2. Involving public figure such celebrities for successful the health promotion program

3. Monitoring and evaluation of the health promotion program for program sustainability.

\section{Conclusion}

In order to have strengthened support in community research, it is supposed to have an engagement in community, stakeholder, academics, and health professionals. Therefore, it should have good communication and trust between community, academics, and health professional when conduct to research and explain the benefit the study for the community. Community-based participatory research (CBPR) is a bridge between science and practice through community engagement and social action to increase health equity. Successfully research depends on CBPR role to establish sustainability program, decision making, and outcomes beneficial to the community. Besides that CBPR, the role of government, particularly Ministry of Health $(\mathrm{MoH})$ has potential influence to release and introduce research program and research in community. Through CBPR, MOH will be easy and fast in implementation the research program, making policy, and sustainability program.

It cannot be avoided that role of a public figure (celebrities) has influenced the success of the program in advertising on TV, radio and social media. Besides that, the power of the head of program advocacy may trigger to absorb community attention in NCDs prevention. For example Invite ministry of Health, top of leaders in any event such as fun run and fun walking, regulation for doing exercise every week for all government and private institution, launching the regulation in video and share it in all social media, TV, Radio, poster in public areas, waiting room in hospitals and clinics and playing the video and advertising on TV with involving celebrity and Government staff. Based on the local policy was important to organize a needs assessment for prevention and control NCDs program with integrity training for a health professional, cadres (volunteer health worker), and dietary educators. It is crucial for making polity on health status, nutrition status, health environment, health attitude, and various health service utilization aspects, blood glucose to estimate diabetes prevalence [21].

Collaboration between Community-based participatory research (CBPR), academics, stakeholder, and community is a crucial to reach sustainability research and program which has potential benefit among community. CBPR may empower and establish strengthened community capacity in research. To conduct and sustain research in community, a trust should be establish from bottom to top leader such head of rural, health professional in clinics, MoH Government staffs, and academics in Universities. They should discuss and have commitment for conducting to 
research, making decision, policy, and strategy. Therefore, the community will have benefit of the research, health program, and will sustain in independent to improve health equity.

\section{References}

[1] World Health Organization. (2018)

[2]Nam Han Cho. (2017). Eighth edition 2017. In IDF Diabetes Atlas, 8th edition. https://doi.org/http://dx.doi. org/10.1016/S0140-6736(16)31679-8 _.................... (2017)

[3] Indonesian Basic Data. (Jakarta: Badan Penelitian dan Pengembangan Kesehatan RI). (2013)

[4] Indonesian Basic Data. (Jakarta: Badan Penelitian dan Pengembangan Kesehatan RI). (2017)

[5] Indonesian Basic Data. (Jakarta: Badan Penelitian dan Pengembangan Kesehatan RI). (2018)

[6] World Health Organization. (2014)

[7] Rusdiana, Savira, M., \& Amelia, R. (2018). The effect of diabetes self-management education on Hba1c level and fasting blood sugar in type 2 diabetes mellitus patients in primary health care in binjai city of north Sumatera, Indonesia. Open Access Macedonian Journal of Medical Sciences, 6(4), 715-718. https://doi.org/10.3889/oamjms.2018.169.....

[8] Utomo, M. R. S., Wungouw, H., \& Marunduh, S. (2015). Kadar Hba1C Pada Pasien Diabetes Melitus Tipe 2 Di Puskesmas Bahu Kecamatan Malalayang Kota Manado. Jurnal E-Biomedik, 3(1), 3-11. https://doi.org/10.35790/ebm.3.1.2015.662.

[9] National Health Service (NHS) ............................... (2013)

[10]World Health Organization. Global Report. (2016). Global Report on Diabetes. Isbn, 978, 6-86. http://www.who.int/about/licensing/..... .(2016)

[11]Ahmad Suryana. National Nutrition Strategy Paper of Indonesia. FAO/WHO.2 ${ }^{\text {nd }}$ International Conference on Nutrition. ICN 2. (2013)

[12] Khor Geok Lin. Asian Dietary Patterns and Health Outcomes. Regional Differences In Food Patterns And Health Implications. 2016 ILSI Annual Meeting (2016)

[13] Indonesian Basic Data. World Health Organisation.

[14] Gakidou. Global Report on Diabetes.

[15] Lipoeto et al: Food consumption patterns and nutrition transition in South-East Asia. Public health nutrition, 16(9), 1637-1643. (2013)

[16] Nova Yanti, Yesi Fadriyanti. Effectiveness of Education Method of Modification CBIA (Interactive Community Based Approach) on Knowledge, Attitude, and Behavoiur, of Daibetes Patients about Foof Care at Andalas Health Center in Padang. International Health Seminar. Health Family, Health Enviroment, Health Country and Free From Violence, Padang, December 20th 2017. .................................. (2017)

[17] Murniati, Herwati, The Effectiveness of Model KIE Setting The Pattern of Diet DM, and Diabetes Feet Gymnastics Through The Illustration Media for DM Patients Knowledge at The Nanggalo Padang Health Center 2017. International Health Seminar. Health Family, Health Enviroment, Health Country and Free From Violence, Padang, December 20th 2017. (2017)

[18] Ariane, C. P. Buku Pintar Posbindu (1st ed.): (Jakarta: Indonesian Ministry of Health). (2019)

[19] Funnell, Martha M., Tammy L. Brown, Belinda P. Childs, Linda B. Haas, Gwen M. Hosey, Brian Jensen, Melinda Maryniuk et al. "National standards for diabetes self-management education." Diabetes care 32, no. Supplement 1 (2009): S87-S94.

[20] Nielson: Where economics and health meet: changing diabetes in indonesia 05 Nama Jurnal vol no. (2013) 
[21] Soewondo, P., Ferrario, A., \& Tahapary, D. L. (2013). Challenges in diabetes management in Indonesia:

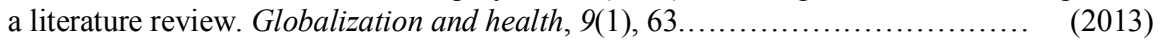

